\title{
RELATIONSHIP BETWEEN PRE AND POST MERGER AND ACQUISITION BANKING INDUSTRY PERFORMANCE IN NIGERIA
}

\author{
Christian U. Amu \\ Federal University of Technology, Nigeria \\ E-mail: chrisuamu@yahoo.com \\ Ezeji Emmanuel Chigbu \\ Federal University of Technology, Nigeria \\ E-mail: sussychigbu@yahoo.com
}

Submission: $23 / 03 / 2015$

Accept: 07/04/2015

\section{ABSTRACT}

The objective of this paper is to analyze the relationship between the pre and post-merger and acquisition performance of banking industry in Nigeria. Aggregate banking data ranging from 1981 to 2013 were analyzed for evidence of correlation between the pre-merger banking performance and post-merger banking performance in Nigeria. The results obtained from the descriptive analysis of the pre and postmerger and acquisition periods shows that the banking industry performance is significantly better after the merger than before the merger. Furthermore, the Pearson correlation coefficients show that absence of relationship between the pre and post-merger period. Overall, the results show that there is significant difference in the performance of Nigerian banking industry in the pre-merger and postmerger and acquisition periods.

Keywords: Merger \& Acquisition, Bank performance, Nigeria. 


\section{INTRODUCTION}

The relevance of banks in the economy of any nation cannot be over emphasized. They are the cornerstones of the economy of a country. The economies of all market-oriented nations depend on the efficient operation of complex and delicately balance system of money and credit. Banks are an indispensable element in these systems. They provide the bulk of the money supply as well as the primary means of facilitating the flow of credit. Consequently, it is submitted that the economic wellbeing of a nation is a function of advancement and development of her banking industry (OBADAN, 1997).

Banks play a crucial role in propelling the entire economy of any nation, of which there is need to reposition it for efficient financial performance through a reform process geared towards forestalling bank distress. In Nigeria, the reform process of the banking sector is part and parcel of the government strategic agenda aimed at repositioning and integrating the Nigerian banking sector into the African regional and global financial system.

To make the Nigerian Banking sector sound according to Ajayi (2005), the sector has undergone remarkable changes over the years in terms of the number of institutions, structure of ownership, as well as depth and breadth of operations. These changes have been influenced mostly by the challenges posed by deregulation of the financial sector, operations, globalization, technological innovations and implementation of supervisory and prudential requirements that conforms to international regulations and standards..

Nigeria banking reform is a product of the global efforts at revamping the world economy. First it was the millennium development goal (MDG), next it was new partnership for Africa Development (NEPAD) Strategy before the National Economic Empowerment and Development Strategy (NEEDS). All these have been things in common: The Economic Development in Nigeria for a long time ranging from the history of policy reforms and developing the banking sector was given priority attention. Various directives were given to the banking sector with the aim of indirectly developing other sectors by propelling the entire economy. 
INDEPENDENT JOURNAL OF MANAGEMENT \& PRODUCTION (IJM\&P)

http://www.ijmp.jor.br

v. 6, n. 3, July - September 2015

ISSN: 2236-269X

DOI: 10.14807/ijmp.v6i3.313

Similarly, a strong and virile economy depends to a very large extent on a robust, stable and reliable financial system including the banking sector. This explains the frequency with which the Nigerian banking sector has witnessed repeated reforms aimed at fine-tuning it to meet up the economic challenges so as to achieve stability and developmental goals which are not only limited to domestic savings mobilization and financial intermediation, but also the elimination of inefficiency to enhance financial efficiency. The financial efficiency parameters are determined and measured by gross earnings, profit after tax, net assets as well as total equity.

Nigeria banking sector has experienced a boom and burst in its cycle in the past 20 to 25 years. After the implementation of the structural adjustment program (SAP) in 1986 and de-regulation of the financial sector, new banks proliferated mainly driven by attractive arbitrage opportunities in the foreign exchange market (BELLO 2007), but prior to the deregulation period, financial intermediation never took off and even declined in the1980's and 1990's. The sector was highly oligopolistic with remarkable features of market concentration and leadership.

Lemo (1997) noted that there were about ten banks that control more than $50 \%$ of the aggregate assets of the banking sector, more than $51 \%$ of the aggregate deposits liabilities and more than $45 \%$ of the aggregate credits. As at then, the banking sector was characterized by small scale banks with high overheads; low capital base averaging less than (\$10 million) ten million Dollars; heavy reliance on the government patronage and loss making. Nigeria's banking sector was still characterized by a high degree of fragmentation and low level of financial intermediation up to 2004 .

Soludo (2004) opines that the Central Bank of Nigeria (CBN) choose to begin the Nigerian banking sector reform process with the consolidation and recapitalization policy through mergers and acquisitions. This is done in order to arrest systems decay, restoration of public confidence, building of strong, competent and competitive players in the global arena, ensuring longevity and higher returns to investors.

Considering the inability of most Nigerian banks to perform well due to operational hardship, expansion bottlenecks as a result of heavy fixed and operating 
INDEPENDENT JOURNAL OF MANAGEMENT \& PRODUCTION (IJM\&P)

http://www.ijmp.jor.br

v. 6, n. 3, July - September 2015

ISSN: 2236-269X

DOI: 10.14807/ijmp.v6i3.313

costs coupled with volatility between deposits and lending rates. Charles Soludo the governor of CBN on July, 6, 2004, increase the capital base of banks to (N25 billion) twenty five billion naira from (N2 billion) two billion, with the objective of creating a sound and more secure banking system that depositors can trust through recapitalization and consolidation program which enhances operational capital base. These and many more, act as a spring board to achieving improved efficiency.

The wave of bank consolidation that recently swept through the banking sector started after the announcement by the CBN on behalf of the federal government of Nigeria, that banks in Nigeria should beef up their minimum capital base to (N25 billion) twenty five billion naira on or before 31st December, 2005. As the termination date for banks consolidation workout drew nearer, desperate efforts were made by the banks to meet the minimum capital fixed by the CBN before the expiration date.

There were many options available towards solving the challenge of recapitalization. A bank could among other options merge with others or acquire smaller ones or volunteer to be acquired by others or do it alone or by combination of two or more of the options. Nevertheless, the strategies adopted by majority of these banks were merger and acquisition. These merger and acquisition brought about a fusion of the 89 banks in the country into mega banks units of only 25 as at $31^{\text {st }}$ December 2005 and later a total of 21 banks presently.

According to CBN report, 25 banks emerged at the end of the first consolidation exercise from the previous 89 banks, while 14 banks were liquidated. The second consolidation exercise left a total of 20 banks in operation with savannah bank regaining its license making it a total of 21 banks presently operating in Nigeria. (UMOREN, 2007)

According to the value increasing school, merger occur broadly because it generate 'synergies' between the acquirer and the target, and synergies in turn increases the value of the firm. The theory of efficiency suggests that merger will only occur when they are expected to generate enough realizable synergies to make the deal beneficial to both parties; it is the symmetric expectations of gains which results in a 'friendly' merger being proposed and accepted. If the gain in value to the target was not positive, it is suggested, the target firm's owners would not sell or submit to 
INDEPENDENT JOURNAL OF MANAGEMENT \& PRODUCTION (IJM\&P)

http://www.ijmp.jor.br

v. 6, n. 3, July - September 2015

ISSN: 2236-269X

DOI: 10.14807/ijmp.v6i3.313

the acquisition, and if the gains were negative to the bidders' owners, the bidder would not complete the deal.

Mergers and acquisitions are a global phenomenon, with an estimated 4,000 deals taking place every year. However, they are not a recent development; five periods of high merger activity, also known as merger waves, occurred in the United States in 1897-1904, 1916-29, 1965-69, 1984-89 and 1993-2000 (ILO, 2001; JIMMY, 2008; MANGOLD; LIPPOK, 2008).

While merger and acquisition started in Nigeria in 2004/2005 with effect from January 1, 2006 under the governorship of Professor Charles Chukwuma Soludo at the Central Bank of Nigeria (CBN). On one month assumption of office/duties, Charles Soludo worked out details of an agenda for repositioning the CBN and the financial system for the $21^{\text {st }}$ century with an outcome of pruning the Nigerian eighty nine (89) Banks that was in existence as at 2004.

Merger and acquisition or any other form of consolidation may influence bank interest rates, competition and transmission mechanism of monetary policy, increase in size and the opportunity for reorganization. It also enhances profit and efficiency that bears marginal costs or gives rise to increase in market power, or both together.

The recent merger and acquisition in the Nigeria banking industry are attracting much attention partly because of the height in revenue generation as well as its competitive advantage. One often held the view of merger and acquisition, especially those involving banks, is that firms are merging just to get bigger. Accompanying this notion is the fear that merging firms grab greater market share, individual freedom and competition are threatened, because bigger is perceived as greater concentration of power. While merger and acquisition have certainly reduce the number of banks nationwide, concentration of power in local banking market have not increased. And the very force of regulatory changes that spurred banks merger and acquisition is also bringing new sources of competition to local banking markets (IKPEFAN; KAZEEM, 2013).

Umoren (2007), posits that merger and acquisition is simply another way of saying survival of the fittest, that is to say a bigger, more efficient, better capitalized and more skilled industry survive why the weaker one's die. It is primarily driven by business continues and or market forces and regulatory interventions. This issues 
INDEPENDENT JOURNAL OF MANAGEMENT \& PRODUCTION (IJM\&P)

http://www.ijmp.jor.br

v. 6, n. 3, July - September 2015

ISSN: 2236-269X

DOI: 10.14807/ijmp.v6i3.313

therefore, which this study intend to address are whether mergers and acquisition will bring about efficient, reliable and sound capital base for the banks that fully embraced merger and/or acquisition and to what extent can bank merger or acquisition boost the confidence of the customers, the investors, the shareholders and ability to finance the real sector of the Economy.

This research work is motivated by the need to look into the Central bank's recent reform (consolidation and recapitalization policy through merger and acquisition) that employed certain measures to strengthen the Nigeria banking industry by drastically increasing the minimum capital requirement from (N2 billion) two billion naira to (N25 billion) twenty five billion naira.

Through review of relevant literatures, analysis of policy documents, official report and economic information on the banking sector, it became evident that the consolidation of banks led to a remarkable reduction in the number of banks from 89 to 25 (as at $31^{\text {st }}$ December 2005) and finally 21 (at present) by merger, acquisition, recapitalization, and other means. Moreover since merger and acquisition cannot be over emphasized, this prompted the researchers' interest to access the perceived impact of merger and acquisition on banks in Nigeria.

This research work will critically evaluate merger and acquisition on Nigeria banks and see if it has resulted in making banks in Nigeria more efficient and reliable and also, if their intermediary potentials have also been revised. Moreover it will access three selected Nigeria banks that underwent merger and acquisition to see if their profitability which is a function of performance has enhanced their stability and consequently the capacity to compete in the global market as well as reshaping the banking industry.

Banks are recently seeing consolidation and recapitalization program through merger and acquisition as an alternative means of re-capitalizing, surviving the global financial meltdown as well as competing favorably in the global arena. The latest reform that compelled all commercial banks to raise their capital base from (N2 billion) two billion naira to (N25 billion) twenty five billion naira on or before $31^{\text {st }}$ December 2005 so as to consolidate the existing banks into fewer, larger and financially stronger and efficient banks sent some of the banks on their heelsconsidering merger and acquisition since it was one of the best options available to 
INDEPENDENT JOURNAL OF MANAGEMENT \& PRODUCTION (IJM\&P)

http://www.ijmp.jor.br

v. 6, n. 3, July - September 2015

ISSN: 2236-269X

DOI: 10.14807/ijmp.v6i3.313

them (SHEPHERD, 2010). Accompanying this notion is a fear that the few market leaders in the industry will grab greater market share hence competition will be threatened since bigger is perceived to have greater concentration of power.

The Nigeria banking system today is fragile and marginal. Our vision is a banking system that is part of the global change, which is strong, efficient, competitive and reliable. It is a banking system which depositors can trust and investors can rely upon. Persistent illiquidity, weak corporate governance, poor assets quality, insider abuse, weak capital base, unprofitable operations and over dependence on public sector funds necessitated the banking sector reform (NNANNA, 2005). Moreover, in recent times, many banks appear to have abandoned their essential intermediation role of mobilizing savings and inculcating banking habit at the household and micro enterprise level (SOLUDO, 2004).

The main objective of this study is to examine the relationship between the pre-merger and post-merger performance of banking industry in Nigeria. This paper therefore contributes to existing literature on merger and acquisition and banking industry performance in Nigeria. The findings are also useful to monetary authority and aid in formulation of banking system capitalization policies. The remainder of the paper is organized as follows. Section 2 presents the empirical literature. Section 3 embodies methodology and data. Section 4 presents the empirical results and discussions, and section 5 concludes the paper.

\section{EMPIRICAL LITERATURE}

Mergers entails the coming together of two or more firms to become one big firm while acquisition is the takeover or purchase of a small firm by a bigger firm, which are both pursuing similar motives. Imala (2005) postulated that the objectives of banking system are to ensure price stability and facilitate rapid economic development.

Regrettably these objectives remained largely unattained in Nigeria as a result of some deficiencies in our banking system, these include; low capital base, as average capital base of Nigeria banks was N10 million which was very low, a large number of small banks with relatively few branches, the dominance of a few banks, poor rating of a number of banks, weak corporate governance evidence by inaccurate reporting and non-compliance with regulatory requirements, insolvency as 
INDEPENDENT JOURNAL OF MANAGEMENT \& PRODUCTION (IJM\&P)

http://www.ijmp.jor.br

v. 6, n. 3, July - September 2015

ISSN: 2236-269X

DOI: 10.14807/ijmp.v6i3.313

evidence by negative capital adequacy ratios of some banks, eroded shareholders fund caused by operating losses, over dependence on public sector deposit, and foreign exchange trading and the neglect of small and medium scale private savers. The Nigeria banking sector plays a marginal role in the development of the real sector.

Accordingly, Soludo (2004) opines that mergers and acquisitions are aimed at achieving cost efficiency through economics of scale, and to diversify and expand on the range of business activities for improved performance.

There are different study of mergers and acquisitions. Several researchers have given different perspectives of mergers and acquisitions. These mergers and acquisitions paradigms include: economic and finance; strategy; organizational behavior and human resource management perspectives (BALMER; DINNIE, 1999; CARTWRIGHT; COOPER, 1992; MILLWARD; KYRIAKIDOU, 2004).

The economic and finance paradigm is primarily interested in the efficiency impact of mergers and acquisitions on the economy through economies of scale and market power with emphasis on market for corporate control. One of the key arguments of the market for corporate control paradigm is that economic value created through acquisition activities is decided by market characteristics including its competitiveness (BALMER; DINNIE, 1999).

Researchers using the strategy paradigm see mergers and acquisitions as a means of corporate growth and diversification, primarily, emphasizing factors that are management controlled such as diversification strategies as a crucial factor in determining post-acquisition performance (MARKS; MIRVIN, 2001).

The primary interests in human resource management perspective are the psychological effects of mergers and acquisitions on individuals such as feelings of tension, alienation and uncertainty.

Moreover, numerous researchers have empirically examined whether mergers and acquisitions are solutions to bank problems (see for example: SZAPERY, 2001; BELLO, 2005; AKINTOYE, 2008; SOMOYE, 2008). Szapery (2001) for instance provides the foundation for a research on the linkage between bank mergers and acquisitions and profitability. 
INDEPENDENT JOURNAL OF MANAGEMENT \& PRODUCTION (IJM\&P)

http://www.ijmp.jor.br

v. 6, n. 3, July - September 2015

ISSN: 2236-269X

DOI: 10.14807/ijmp.v6i3.313

Evidence provided by Kama (2006) suggests that mergers and acquisitions in the financial system could impact positively on the efficiency of most banks. Surprisingly, the available empirical evidence suggests that mergers and acquisitions operations in the United States banking industry have not had a positive influence on performance in terms of efficiency.

Many researchers have attempted to examine the effect of mergers and acquisitions on the efficiency of the banking industry. For instance, Tripe (2000) analyzed a small sample of seven to fourteen banks, employed accounting ratios and two Data Envelopment Analysis (DEA) models to explore the efficiency of six banks mergers in New Zealand between 1989 and 1998.

They found that the acquiring banks to be generally larger than their existing ones, although they were not consistently more efficient. They found that five or six merged banks had efficiency gains based on the financial ratios while another only achieved a slight improvement in operating expenses to average total income. Based on DEA analysis, they found that only some merged banks were more efficient than the target banks pre-merger. The results suggest that four banks had obvious efficiency gains post-merger.

Gourlay (2006) examined the efficiency gains from mergers among Indian Banks over the period 1991-1992 to 2004-2005 and observed that the mergers led to improvement of efficiency for the merging banks.

Also, evidence supporting mergers and acquisitions to achieve cost saving and efficiency gain is sparse (KWAN; EISENBEIS, 1999). Akvein, Berger and Humphrey (1997) analyze changes in profitability experienced in the same set of large mergers. They found that banking organizations significantly improved their profit efficiency ranking after mergers.

De Young (1997) finds out that when both the acquirer and target were poor performers, mergers resulted in improving their performance. Healy, Palepu and Ruback (1992) examine all commercial banks and bank holding company mergers and acquisitions occurring between 1982 and 1986. They found that mergers and acquisitions did not reduce non-interest expenses that could have led to improved efficiency. 
INDEPENDENT JOURNAL OF MANAGEMENT \& PRODUCTION (IJM\&P)

http://www.ijmp.jor.br

v. 6, n. 3, July - September 2015

ISSN: 2236-269X

DOI: 10.14807/ijmp.v6i3.313

According to Pilloff and Santomero (1997), there is little empirical evidence of mergers achieving growth or other important performance gains. Their finding undermines a major rationale for mergers and consequently raised doubt about other benefits mergers and acquisitions may provide to businesses.

However, Kay (1993) finds some evidence of superior post-merger period because of the merged firms' enhanced ability to attract loans. They also show increased employee productivity and net asset growth. Also, this is evident in the Nigeria's banking industry (OKPANACHI, 2007).

Walter and Uche (2005) posit that mergers and acquisitions made Nigerian banks more efficient. They used table to present their data which was analyzed using simple percentage. Akpan (2007) using chi-square to test his stated hypothesis found that the policy of consolidation and recapitalization has ensured customer's confidence in the Nigerian banking industry in terms of high profit. But for Sobowale (2004) and Osho (2004), it is expected that the value of the companies that participated in mergers and acquisitions activities would be higher than before because future dividends and earning streams are expected to rise and subsequently improves efficiency.

Similarly, Uchendu (2005) and Kama (2007) opine that, the bank consolidation which took place in Malaysia facilitated banks expansion which led to growth in their banking sector. In a related study of the Chilean banking industry, Kwan (2007) finds that the experience in Chile was mainly from productivity's improvement from the large banks formed as a result of mergers and acquisitions.

Surprisingly, the majority of studies comparing pre and post mergers performance found that, this potential efficiency derived from mergers and acquisitions rarely materialize (AKVEIN et al., 1997). Towards this end, Beital, Schiereck and Wahrenbur (2003) finds no gain effect due to mergers and acquisitions, but for Kama (2007), mergers and acquisitions played an important role in improving banking performance after merger and financial performance which is a stimulus for efficiency.

Ikpefan and Kazeem (2013) examines the impacts of merger on deposit money banks performance in Nigeria between 2000 and 2009 using panel data (c) (†) [http://creativecommons.org/licenses/by/3.0/us/]

Licensed under a Creative Commons Attribution 3.0 United States License 
INDEPENDENT JOURNAL OF MANAGEMENT \& PRODUCTION (IJM\&P)

http://www.ijmp.jor.br

v. 6, n. 3, July - September 2015

ISSN: 2236-269X

DOI: 10.14807/ijmp.v6i3.313

ordinary least squares approach is the methodology. The results shows that merger created synergy as indicated by the statistically significant increasing post-merger financial performances although banks should not jump at any merging opportunity that offers itself because the exercise is not an opportunistic one. They therefore recommend that merger being a relatively new phenomenon in the Nigerian banking environment should be given more encouragement by the regulatory authorities.

\section{METHODOLOGY AND DATA}

\subsection{Methodology}

To investigate relationship between pre and post-merger and acquisition banking sector performance in Nigeria, we adopt descriptive analysis and correlation analysis. Descriptive analysis is the presentation of summary of the important statistics in a data set. Our descriptive statistics involve plotting of time series graph and computation of mean, standard deviation, skewness, kurtosis, and Jarque-Bera statistic for the level and first difference of the pre and post-merger and acquisition series of private sector deposit and banking sector net assets, which serve as the proxy for banking industry performance in Nigeria. While the mean presents information on the average banking industry performance, the standard deviation shows the level of variation of the series from their average. The skewness and the kurtosis provide insight into their distributional pattern.

The correlation analysis, on the other hand, was conducted using Pearson product moment correlation method. The Pearson correlation coefficient is a measure of the strength relationship between two variables $X$ and $Y$. It is computed by dividing sample covariance by the product of standard deviations of $X$ and $Y$ thus:

$$
r_{x, y}=\frac{S_{x y}}{S_{x} S_{y}}=\frac{\Sigma X_{i} Y_{i}-\left(\Sigma X_{i} Y\right) / n}{\sqrt{\Sigma X_{i}^{2}-\left(\Sigma X_{i}\right)^{2 / n}} \sqrt{\Sigma Y_{i}^{2}-\left(\Sigma Y_{i}^{2}\right)^{2 / n}}},
$$

Where, $r_{x y}$ is the Pearson product moment correlation or the sample correlation coefficient, $S_{x y}$ is the sample variance, $S_{x}$ is the sample standard deviation of $X$ and $S_{y}$ is the sample standard deviation of $Y$. The $X$ and $Y$ here represent pre and post-merger and acquisition performance of the banking industry in Nigeria.

The correlation coefficient measures the strength of linear dependence between the pre and post-merger and acquisition performance of the banking 
INDEPENDENT JOURNAL OF MANAGEMENT \& PRODUCTION (IJM\&P)

http://www.ijmp.jor.br

v. 6, n. 3, July - September 2015

ISSN: 2236-269X

DOI: 10.14807/ijmp.v6i3.313

industry in Nigeria. The two random variables are uncorrelated if $r_{x, y}=0$. The closer the correlation coefficient to 1 , the more the two variables is correlated

\subsection{Description of Data}

The data for this study was generated from secondary sources. The data consist of the annual private sector deposit (PSD) with the commercial banks and banking sector net assets (BSNA); the PSD and BSNA serve as the proxy for banking industry performance. The data were obtained the Central Bank of Nigeria Statistical Bulletin 2013 The period under consideration begins from 1981 and ends on 2013.

\section{Empirical Results}

Figure 1, 2 and 3 below display Time Series graphical summary of the relationship between pre and post-merger and acquisition Private Sector Deposit and Banking Sector Net Assets. The pre-merger period is the period before 2004 and the post-merger period is from 2006. From the time series graph displayed on Figure 1 to 3 , we visualize that the series do not behave alike.

This suggests that the pre and post-merger and acquisition periods in the Nigerian banking history may not be the same. But the graphs do not indicate whether the banking industry perform well in the pre-merger period or in the postmerger period. Another noticeable behavior of the series is the lack of clarity on the nature of stationary of the series in both periods.

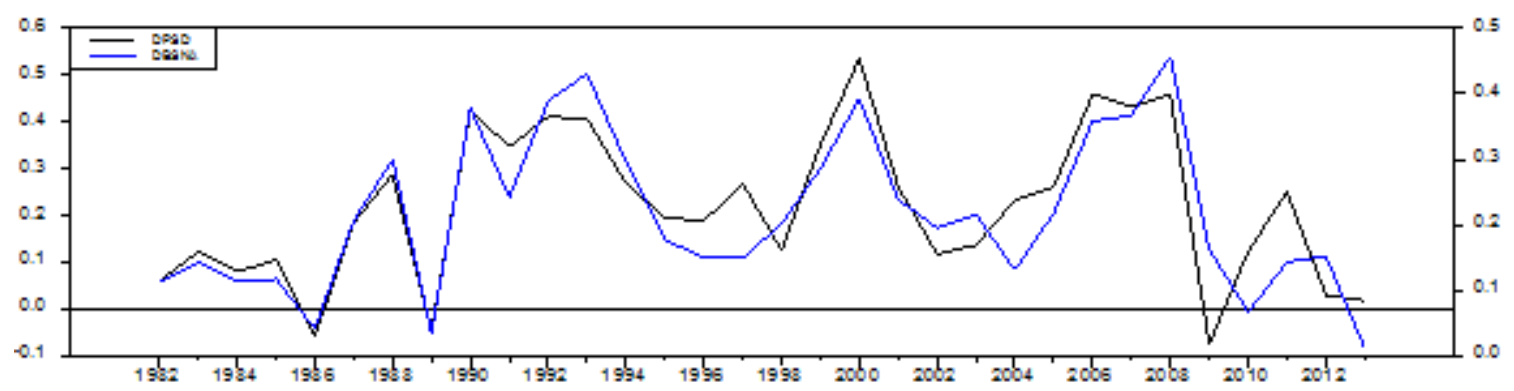

Figure 1: Time series plot of depositors' confidence and banking sector net assets 1981 to 2013 
INDEPENDENT JOURNAL OF MANAGEMENT \& PRODUCTION (IJM\&P)

http://www.ijmp.jor.br

ISSN: 2236-269X

DOI: 10.14807/ijmp.v6i3.313

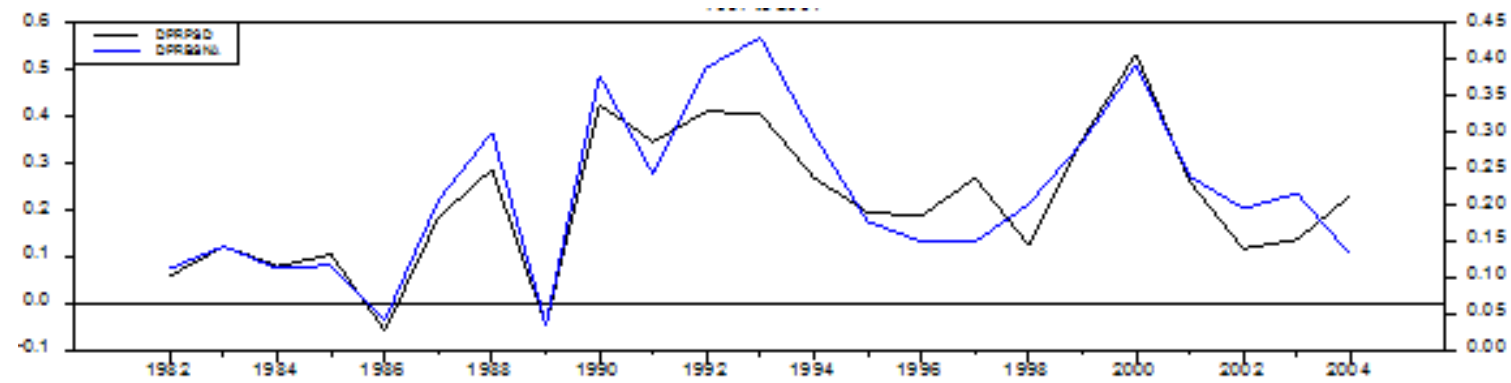

Figure 2: Time series plot of pre-merger private sector deposit and banking net assets 1981 to 2004

Table 1 displays the descriptive statistics for the banking sector in the premerger and acquisition period and post-merger and acquisition period in Nigeria. We observe, from Table 1, that the average pre-merger banking sector deposit was N145.8 billion but increased to N3.4 trillion in the post-merger and acquisition period. This represents $2245 \%$ increase in the banking sector deposit in the post-merger period.

Also, the standard deviation of the post-merger private sector deposit also increased by $633 \%$ over its value in the pre-merger period. In the same vein, the banking sector net assets increased from $\mathrm{N} 481$ billion in the pre-merger period to N9.8 trillion in the post-merger and acquisition period; representing 1944\% change in banking sector assets. Another noticeable feature of Table 1 is the distribution of the banking industry performance in the pre and post-merger and acquisition periods. The two series (PSD and BSNA) appear to be normally distributed in pre-merger period but not normally distributed before merger, except for kurtosis, which show evidence of normal distribution.

Table 1: Descriptive Statistics of Banking Sector Performance

\begin{tabular}{|c|c|c|c|c|c|}
\hline & Mean & Std. Dev. & Kurtosis & Skewness & Jarque-Bera \\
\hline \multicolumn{6}{|c|}{ PSD Level Series } \\
\hline Pre-Merger & 145.80 & 211.55 & $1.657^{*}$ & 1.646 & 13.592 \\
\hline Post-Merger & 3419.06 & 1552.29 & $-1.145^{*}$ & $-0.443^{*}$ & $0.787^{*}$ \\
\hline \multicolumn{6}{|c|}{ PSD Change Series } \\
\hline Pre-Merger & 0.253 & 0.140 & 1.411 & 1.170 & $13.592(0.001)$ \\
\hline Post-Merger & 0.211 & 0.218 & -1.998 & 0.056 & $0.787(0.674)$ \\
\hline \multicolumn{6}{|c|}{ BSNA Level Series } \\
\hline Pre-Merger & 481.39 & 666.06 & $1.672^{*}$ & 1.632 & 13.460 \\
\hline Post-Merger & 9842.42 & 4761.56 & $-1.359^{*}$ & $-0.275^{*}$ & $0.806^{*}$ \\
\hline \multicolumn{6}{|c|}{ BSNA Change Series } \\
\hline Pre-Merger & 0.226 & 0.082 & 1.599 & 1.149 & $13.460(0.001)$ \\
\hline Post-Merger & 0.214 & 0.158 & -1.363 & 0.390 & $0.806(0.668)$ \\
\hline
\end{tabular}


INDEPENDENT JOURNAL OF MANAGEMENT \& PRODUCTION (IJM\&P)

In Table 2, we present results of the paired two samples for means using ttest. This was used to examine the mean for the pre and post-merger and acquisition private sector deposit as well as the mean for the pre and post-merger periods for the banking sector net assets series. Notice from Table two that the hypothesized mean difference of zero $(0)$ in these two cases are not true.

This leads to rejection of the null hypotheses of zero mean difference for the pre and post-merger period for the PSD and BSNA. This rejection is not surprising given that the banking industry private sector deposit increased in the post-merger period by $2245 \%$ from its value in the pre-merger period. Similarly, the banking sector net asset also increased by $1944 \%$ in the post-merger period from N481 billion before the merger. This result therefore supports the notion that merger and acquisition is a catalyst for the development of banking industry in Nigeria.

Table 2: t-Test: Paired Two Sample for Means

\begin{tabular}{lrr}
\hline & Pre and Post PSD & Pre and Post BSNA \\
\hline Hypothesized Mean Difference & 0 & 0 \\
\hline Df & 7 & 7 \\
\hline $\mathrm{t}$ Stat & 0.402792 & 0.194339 \\
\hline $\mathrm{P}(\mathrm{T}<=\mathrm{t})$ one-tail & 0.349559 & 0.425715 \\
\hline $\mathrm{t}$ Critical one-tail & 1.894579 & 1.894579 \\
\hline $\mathrm{P}(\mathrm{T}<=\mathrm{t})$ two-tail & 0.699119 & 0.85143 \\
\hline $\mathrm{t}$ Critical two-tail & 2.364624 & 2.364624 \\
\hline
\end{tabular}

Table 3 below presents the Pearson correlation coefficients for the pre and post-merger and acquisition for the private sector deposit as well as for the banking sector net asset. Notice from the table that the pre-merger and post-merger performances of the private sector deposits are negative but not linearly related. On the other hand, the pre-merger and post-merger performances of the banking sector net assets are positive but not linearly related. Generally, these results show that significant difference in the Nigerian banking industry performance in the pre-merger and post-merger periods.

Table 3: Pearson Correlation Coefficients

Pre and Post PSD Pre and Post BSNA

\begin{tabular}{lll}
\hline Pearson Correlation & -0.28708 & 0.119858
\end{tabular}


INDEPENDENT JOURNAL OF MANAGEMENT \& PRODUCTION (IJM\&P)

http://www.ijmp.jor.br

v. 6, n. 3, July - September 2015

ISSN: 2236-269X

DOI: 10.14807/ijmp.v6i3.313

\section{Conclusions}

The objective of this paper is to analyze the performance of the Nigerian banking industry before the 2004/2005 merger and acquisition and after the merger and acquisition periods using descriptive statistics and correlation analysis for the 1981 to 2013 sample period.

The descriptive analysis of the pre and post-merger and acquisition periods shows that the banking industry performance is significantly better after the merger than before the merger. This is evident in the significant increase in the private sector deposit and banking sector net assets. It further shows that the post-merger banking performance is normally distributed.

The coefficients of the Pearson correlation conducted to show the relationship between the pre and post-merger periods, did show any relationship between the pre and post-merger periods. Overall, the results show that there is significant difference in the performance of Nigerian banking industry in the pre-merger and post-merger and acquisition periods.

\section{REFERENCES}

AJAYI, M. (2005) Banking Sector Reforms and Bank Consolidation in Nigeria, Bullion CBN Publication, v. 29, n. 2, p. 4-5.

AKINTOYE, R. (2008) Activity in the Nigerian Banking Industry: Some Clarifying Comments, International Research Journal of Finance \& Economics, n. 19, p. 65.

BALMER, J.; DINNIE, K. (1999) The Antidote to Merger Madness, Corporate Identity \& Corporate Communications, v. 4, n. 4, p. 182-187.

BELLO, Y. A. (2005) Banking Sector Reforms and Bank Consolidation in Nigeria, Bullion CBN Publication, v. 29, n. 2, p. 48.

CARTWRIGHT, S.; COOPER, C. (1992) Managing Mergers and Strategic Alliances: Integrating People and Cultures, Oxford, Elsevier, p. 6.

IKPEFAN, O. A.; KAZEEM, B. L. O. (2013) The Effect of Merger on Deposit Money Banks Performance in the Nigerian Banking Industry, Journal of Applied Finance \& Banking, v. 3, n. 4, p. 105-123.

IMALA .O. A. (2005) Challenges of Banking Sector Reforms \& Bank Consolidation in Nigeria, Bullion, v. 29, n. 2, p. 27.

KAMA, U. (2006) Recent Reforms in the Nigerian Banking Industry: Issues and Challenges, Bullion. A Publication of CBN Pp 50-53.

NNANNA, O. J. (2005) Beyond Bank Consolidation: The Impact on Society', A Paper Presented at the Annual CBN Fourth Monetary Policy Conference held in Abuja, 18th - 19th November. 
SHERPHERD, A. (2010) Mergers and Acquisitions in the Nigerian Banking Industry: An Advocate of three Mega Banks, European Journal of Social Sciences, v. 15, n. 4, p. 555

SOLUDO, C. (2004) Consolidating the Nigerian Banking Industry to Meet the Development Challenges of the 21st Century, Being an address delivered to the Special Meeting of the Bankers Committee, held on July 6, at the CBN Headquarter, Abuja.

SOMOYE, R. O. C. (2008) The Performance of Commercial Banks in Post Consolidation Period in Nigeria: An empirical review, European Journal of Economics, Finance and Administrative Science, n. 14, p. 63-64.

UMOREN, A. O. (2007) Merger and Acquisitions in Nigerian: Analysis of performance in Pre and Post Consolidation Era, Journal of Banking \& Finance and Economics, p. 151-153. 